\title{
Transforming Obligation in William James
}

ReLigious LANGUAGE and ideas course through William James's essays like a rough breeze. James finds vital strength in religion, and almost all of his philosophical reflections incorporate religious themes. He self-consciously affirms his devotion when he says, "Religion is the great interest of my life."1 A part of his interest is in the unfinished and unanticipated character of religious impulse and meaning. The exigencies of the spirit blow where they might, and they often propel James into saying things that he, or his later followers, might sometimes wish he had left unsaid. But his openness to the influence of spiritual forces, and his demand that the philosophical life pay attention to this influence, separates James from most other philosophers. His philosophical writings often border on affective manipulation as he tries to change, not only what his readers think, but also what they feel. I am sure he writes this way because he feels he has been manipulated in the same manner by the reality of the universe. In the spirit of truth, James knows no better occupation than discovering what sponsors such movement in his character and what the results might be if this prime mover is followed without fear.

Despite James's religious character and my own focus on the meaning of conversion in this book, I turn to James reluctantly. His influence has overwhelmed American Christianity and philosophy. It is hard to stand at a critical distance from James without risking offense to many of our more fondly held beliefs. The ultimate privacy of religious experience, the failure of organized religion to meet the deeper needs of religious people, the pragmatic justification for the freedom of the will, and the need for a radically empirical approach to the problems of reflection are a few of these beliefs for which James is largely responsible. As Stanley Hauerwas observes, "The challenge facing Christians today is that James's world has so thoroughly become 'our' world that we can imagine nothing else." I I agree with Hauerwas's observation and would extend it to American philosophy's dependence 
on naturalism. Many philosophers, and most American philosophers, cannot imagine a philosophy of religion that varies substantially from James. I think this is a problem, because anything that limits imagination often leads to a reduction of genuine inquiry.

James did not intend to become a stumbling block to philosophical or religious inquiry, as Ellen Kappy Suckiel convincingly shows. ${ }^{3} \mathrm{He}$ wanted to open up the world, not close it down. That his work has become a kind of restraining limit to reflection is largely our fault. We want to believe as James believed. We want to hide in his penumbra without facing the difficult issues ourselves. Nevertheless, I think James must bear his share of the responsibility for the present poor condition of our religious and philosophical reflection on personal transformation. James leads us down a fair path, but I fear he walks away from-and consequently leads us away from-the kinds of discoveries that can better ground our reflection and action.

James writes as an observer of religious value, claiming the distance of an objective observer. With the presentation of these observations, he produces a powerful argument that reforms the way we think about religious obligation and personal transformation. James's reforming intention is evident in Varieties of Religious Experience (VRE), particularly in his treatment of conversion. When his survey of religious experience reaches this central Christian tenet-that God's active spirit changes the form and character of human lives-James departs from his purely observational stance and sharply critiques the belief that religious change is dependent on content or ideas apart from the self. His critique is interesting for several reasons, as we shall see. In general terms, it reveals a shift in James's approach-from seeking to discover the grounds of religious experience and transformation to seeking to determine the ground of personal transformation. Simply put, James wants to mold religious experience in his own way. Sorting out James's resistance to the traditional understanding of conversion will not only clarify part of the ambiguity in his treatment of religion, but it will also enable us to articulate more clearly the dialectic internal to classical American philosophy over ultimate personal change and the extrahuman grounds of such a transformation as conversion.

The plan of the present study is to describe the connection between the obligation James finds in the reflective life and the resultant personal transformation that provides access to the meaning of that obligation. 
The relation between obligation and transformation leads James to claim that the development of personal character is a proper aim of philosophical inquiry. I will develop this line of thought by following James's treatment of conversion in Varieties. As I show, James uses his analysis of character and personal transformation to separate himself clearly from the traditional doctrine of religious conversion, and particularly from Jonathan Edwards. I conclude with an analysis and critique of James's position against conversion and ask what this means for his work in transforming the obligation to the religious life.

\section{The Obligation to Transformation}

In his early essays, William James shows little interest in pedestrian topics such as the epistemological and metaphysical status of general concepts. Rather, he seeks to understand why men philosophize by exploring the motive behind their reflection. He wants to weigh in on the question of whether or not the universe is a moral game. If it is not, James observes, there is little need for the regretful hand wringing that occupies much of our living and thinking. But if the universe is a moral game, then it does matter what we do, and why we do it. It was in beginning to sort out the question of the moral universe that James realized there must be a restive condition common to reflective persons. He calls this condition obligation. Without some sense of obligation, a prerational form of an "ought," there would be no vital connection between acting and thinking. There would be no demand to be reflective at all.

In the essay "The Moral Philosopher and the Moral Life" James argues that an obligation emerges within the reconciling function of thought. Our primary objective is not to change the world or our selves but to achieve intellectual rest with our selves and the world. The path toward this elusive intellectual peace requires sensitivity to motive forces in action and a willingness to articulate the character of obligation that informs our reflection.

Accounting for this motive force in the reflective life leads James to two speculative conclusions. The first is that "goodness, badness, and obligation must be realized somewhere in order to really exist; and the first step in ethical philosophy is to see that no merely inorganic "nature of things' can realize them" (Will to Believe [WTB] 150). A second conclusion is "that the essence of good is simply to satisfy demand. The demand 
may be for anything under the sun" (WTB 153). James's first suggestion here, that no obligation can be real unless it is fully realized in some form, leads to a hypothetical connection between God and morality. Without a supreme obligator, there is no temporal possibility for understanding the drive for strenuous moral living. Interest and excitement in living the good life with vigor must have a tangible ground - this way of life must fulfill a discrete obligation. Idealism will not suffice to explain the vigor of concrete moral action.

James's second speculative conclusion, whatever the good is it must at some point satisfy a demand, gives us the range of his moral thought. On one pole stands the moral philosopher, who is good to the extent that a demand is satisfied. At the opposite pole is whatever originates the obligation, and this origin is good in terms of demanding action continuous with the abilities and affections of reflective persons. The obligation comprises the middle ground of good in humans and the good of the universe. "The philosopher, therefore," James says, “who seeks to know which ideal ought to have supreme weight and which one ought to be subordinated, must trace the ought itself to the de facto constitution of some existing consciousness, behind which, as one of the data of the universe, he as a purely ethical philosopher is unable to go. This consciousness must make the one ideal right by feeling it to be right, the other wrong by feeling it to be wrong" (WTB 147). James extends the ontological character of this "feeling" a step further when he adds, "we see not only that without a claim actually made by some concrete person there can be no obligation, but that there is some obligation wherever there is a claim." Obligation, in other words, is simply a feature of the claim. There is no ground for separation or dialectic. Statements like these seem to suggest that James holds to a kind of moral intuitionism, but his emphasis on "some claim" and "some concrete person" muddies the waters on this point. It is not clear how he could arrive by intuition at the feet of "some concrete person." The problem here is akin to the discontinuity that Charlene Haddock Siegfried indicates in the larger flow of the "Moral Philosopher," where James "takes back this ethics developed in light of our finite temporality" by saying that ethics must wait on metaphysical and theological beliefs to be final. ${ }^{4}$

James lays stress on the character of obligation itself at this point. It has the feel of something objective and external, something organically authoritative over the moral philosopher. A moral philosopher is a person 
who has become aware of this obligation and is thus awakened to the changes in action that follow. Ignoring this obligation reduces one's ability to live as a human being, but living in its observance implies the difficult task of self-judgment.

Self-judgment, however, is not a sufficient response for the moral philosopher. James says, "Obligations can thus exist inside a single thinker's consciousness; and perfect peace can abide with him only so far as he lives according to some casuistic scale which keeps his more imperative goods on top" (WTB 159). Perfect peace may sound a bit fantastic, but I think this is one example of James's tendency to use scriptural phrases to bolster his point. And though, in this example, perfect peace is an extreme point, an elusive and impossible task, such is the focus for persons who try to make their way by piecemeal judgments toward a moral existence. James is leading his reader toward the unsatisfactory limit of the casuistic response. Simply judging between obligations is not enough. Rather, James pushes the reader to recognize moral obligation as a force pressing us beyond the ability to judge between imperative goods, and toward a metaphysical realization of character.

Only this pressure toward a dramatic realization of character explains what James means by an awareness of obligation. That a moral principle is "not made up in advance" means that it has some other ground, something else giving it stability. And James is fascinated with the kind of action undertaken where the immediate good is not apparent. The ability to endure hardship for the sake of a more imperative good is the sign of a moral life. The division in human character between persons who respond to this kind of obligation with strenuous action and those who affect an easygoing mood is most distinctive in James:

The deepest difference, practically, in the moral life of man is the difference between the easy-going and the strenuous mood. When in the easygoing mood the shrinking from present ill is our ruling consideration. The strenuous mood, on the contrary, makes us quite indifferent to present ill, if only the greater ideal be attained. The capacity for the strenuous mood probably lies slumbering in every man, but it has more difficulty in some than in others in waking up. It needs the wilder passions to arouse it, the big fears, loves, and indignations; or else the deeply penetrating appeal of some one of the higher fidelities, like justice, truth, or freedom. ... When, however, we believe that a God is there, and that he is one of the claimants, the infinite perspective opens out. The scale of the symphony is incalculably prolonged. The more imperative ideals now 
begin to speak with an altogether new objectivity and significance, and to utter the penetrating, shattering, tragically challenging note of appeal. . . . The capacity for the strenuous mood lies so deep down among our natural human possibilities that even if there were no metaphysical or traditional grounds for believing in a God, men would postulate one simply as a pretext for living hard, and getting out of the game of existence its keenest possibilities of zest. (WTB 160)

James's rhetorical power here is admirable, especially as he moves seamlessly from human moods to the infinite moral claimant, God.The strenuous mood is the character of a person who responds to the challenging note of moral obligation-whatever the cost, however dark the outlook, the person is aroused to enter the fray. The capacity for living in the "strenuous mood," James argues, lies deep among our natural human capacities. It lies buried within us, but active, seeking manifestation and opening into universal meaning. The reflective life is a part of the impulse to engage the "wilder passions" so as to awaken this character in us. Given our human capacity and the objectivity of compelling ideals, it seems strange to think that anyone would willingly stand on the side of the easygoing life, ignorant and unresponsive to the obligation that yields the keenest possibilities of zest in existence. Strength seems to bubble up from James's description of the moral life, and the positive character of the philosopher rises above the superficial problems and contradictions that haunt intellectual accounts of this life. God does not overcome contradictions, and besides, we can exercise our deepest moral capacity within the ambiguities of the reflective life. ${ }^{5}$

Despite this positive word about the reach of our natural capacities, raising this kind of obligation as the goal of reflection puts James at odds with both philosophy and religion. Responding to a felt obligation means moving philosophy beyond its traditional role as an abstract discipline, and many philosophers will resist making such a move. James, however, points to a guiding sentiment that lies beneath the practice of philosophy, its particular topics, and the facts of experience upon which it must work. If not awakened to the reality of moral obligation, the philosopher stands compromised, an unwise lover of wisdom. The strenuous mood is a direct challenge to philosophy.

James raises a two-headed specter for religion. First, the God religion serves may be a self-created god of easy satisfaction, and not a "God-forstrenuous-living." Second, even if there is no God, people may have 
good reason to invent one for the sake of living well. Religious traditions may be well rehearsed and useful, and terribly mistaken.

James's critique of philosophical and religious practice remains veiled in the "Moral Philosopher" as he struggles to grasp the buried character of moral reflection and draw it out of the habits and clichés caked around it. He shakes obligation loose from the glozing of idealism and the false face of rationalism. To see this obligation means a spirit of unrest, action without full grasp of consequence, will without belief. Religion is of interest precisely because it sponsors practices that translate an obligation that does not rely on explicit formulation. Philosophy, especially idealism, resists this demand for particular action unsupported by theoretical wires. Philosophy is morally recalcitrant in its dreamy satisfaction with theory divorced from the actual facts of life, comfortable with smooth intellectual formulations that avoid the coarse texture of intellectual unrest in light of an obliging reality. While religion always moves toward praxis, philosophy does not. James sounds a clarion call for philosophers to face this failure of philosophy, and this is the reason he writes philosophical essays rather than sermons. James is an evangelical philosopher for philosophy. He will reproach religion for other errors later.

Let me return for a moment to the ontology lurking in James's account of obligation. This ontology finds its fullest form in later essays where James expands the ground of moral action to a more universal application. In "Pragmatism and Religion," he writes, "The only real reason I can think of why anything should ever come is that someone wishes it to be here. It is demanded,- - demanded, it may be, to give relief to no matter how small a fraction of the world's mass." 6 The ontological character of demand is peculiar. The "what is" depends on "what relieves," and further, "what is" can be realized only in the action of persons who are awakened to the reality of "what relieves" that produces the charge to live the strenuous life. Moral life is a transformation of the easygoing life. I think James's point in "Pragmatism and Religion" is that nothing beyond this transformation explains the creative power in the universe, and that obligation is all that is needed to realize fully this creative power. Moral living is equivalent to dwelling in the ontological fabric of the universe.

Few philosophers have utilized the persuasive philosophical essay better than William James. His intuitive sensibility of the philosophical and spiritual condition of his auditors guides him in how far he and they can travel together. This distance is often astounding, as when "Moral 
Philosopher and the Moral Life" begins with the claim that there is no ethical philosophy made up in advance. That essay concludes this way:

"See, I have set before thee this day life and good and death and evil; therefore choose life that thou and thy seed may live"-when this challenge comes to us, it is simply our total character and personal genius that are on trial; and if we invoke any so-called philosophy, our choice and use of that also are but revelations of our personal aptitude or incapacity for moral life. From this unsparing practical ordeal no professor's lectures and no array of books can save us. The solving word, for the learned and the unlearned man alike, lies in the last resort in the dumb willingness and unwillingnesses of their interior characters, and nowhere else. It is not in heaven, neither is it beyond the sea; but the word is very nigh unto thee, in thy mouth and in thy heart, that thou mayest do it. (WTB 162)

These words build on Paul's exhortation in Romans 10:5-8, but James inserts his own meaning in the frame of Moses' and Paul's exhortation. In place of the Law, which Moses warns is not beyond the sea but in the mouth and the heart, James inserts the willingnesses and unwillingnesses of the interior character. And James stops his quotation of St. Paul short of verses 9 and 10, where the apostle supplies his understanding of the content in question here: "That is the word of faith which we preach; because if you confess with your lips that Jesus is Lord and believe in your heart that God raised him from the dead, you will be saved. For man believes with his heart and is so justified, and he confesses with his lips and so is saved." This is the word of faith that Paul claims is "nigh unto thee," on our lips and in our hearts. The demand for a transformation of character, a change in our willingness to cleave to the moral life, is equivalent to the persistence and power of the Law for Moses and the confession of Jesus for Paul. James is not subtle in his use of this text. Ultimate meaning, he exhorts his readers, is available in the way one chooses to live. The transformation of one's character is all that can be called to witness for the appropriation of ultimate meaning, and the ability to choose is all the ground one needs to make such an appropriation.

\section{Character And Philosophy}

Philosophy does not comprise neutral ground for James. Philosophy is instead an expression of a person's character and temperament. Rather 
than establish sufficient distance to enable a person to evaluate analytic claims critically, philosophy is a task that reveals and solidifies one's character. What is at stake in philosophical reflection is the apocalypse, the unveiling, of the philosopher. Confession, especially by philosophers, is a difficult task. Pragmatism's general insistence on confessional philosophy is one reason I think logical positivism found a fertile field among American intellectuals in the middle of the last century. Rather than endure the discomfort of confessional reflection required by thinkers like James, philosophers found it easier to ask what it is like to be a bat.

James, however, meets the soulful questions of confessional discourse with an ease that is not just elegant, but also inspiring. His demand that philosophers enter confessional waters requires James to offer his own character as the potential result of such difficult work. "By their fruits," he says repeatedly, "shall you know them." I think the realization of the importance of his own life to his philosophical project leads James to shift from the exuberance of discovery in his earlier essays to more of a defensive character in some of his later writings. James drifts from an attitude of provoking a desire for a better self to defending the claim that a better self is the source of the obligation to the moral life. This is a crucial shift since it alters the ground from which he will argue that his or any person's character is sufficient.

The demand for a sufficiency of character appears throughout James's work. This sufficiency requires openness to satisfying as many demands as possible. A temperament of openness places the person in the mainstream of the moral current of the universe. It is only against this current that we can discover our willingness or unwillingness to live the strenuous life. Yet, in James's later essays, the search for salvation through action leads to the claim that the person acting is the salvation, not only of himself or herself, but of the world. James writes in "Pragmatism and Religion,"

Every such ideal realized will be one moment in the world's salvation. But these particular ideals are not bare abstract possibilities. They are grounded, they are live possibilities, for we are their live champions and pledges, and if the complementary conditions come and add themselves, our ideals will become actual things. What now are the complimentary conditions? They are first such a mixture of things as will in the fullness of time give us the chance, a gap that we can spring into, and, finally, our act. ${ }^{7}$

All that can be required of us, James asserts, is what is possible in action. If an ideal cannot be discovered within the active capacity and freedom 
of the person, then it is not a true potential or ideal. The impossibility of realization is one reason James rejects the imitation of Christ as a proper content for religious practice. If complete Christ-likeness is impossible for mortal sinners, then it cannot serve as the kind of ideal to which we are truly drawn to act.

Clearly, James thinks the reflective life leads to this place where action secures those ideals that are the salvation of the world. He is also aware that there is a temperament behind this activity that requires dedication to ideal action. Such a temperament is realized only through an interaction with the prospective meaning of this life. It cannot be generated by intellectual castle-building or wishful thinking. The philosopher either responds to this reality or remains insensible to it. What kind of transformation is it that makes engagement in the kind of action James here suggests possible, where strenuous living reaches beyond the immediate occasion and becomes the good of the universe? Where does this conviction originate, and what warrants it? How does this ideal form of human action take shape in a person's character and philosophy?

The origin of James's dependence on human transformation, it would seem, lies more in existential than metaphysical confidence, though I do not think these can ever be completely separated. To raise questions about the function of transformation in James's philosophy, as I am doing here, means asking where this task begins for him. We must ask what inspires his willingness not only to engage the demand for transformation, but also to approach transformation as an acceptable content for reflection. What does the transformation he describes seek to overcome?

John McDermott calls attention to an event in James's youth that sheds light on his interest in a transformation of character. In what we now know is an autobiographical account of a "vastation," an experience of emptiness, James writes,

[T]here fell upon me without any warning, just as if it had come out of the darkness, a horrible fear of my own existence. Simultaneously there arose in my mind the image of an epileptic patient who I had seen in the asylum. A black-haired youth with greenish skin, entirely idiotic, who used to sit all day on one of the benches, or rather shelves against the wall, with his knees drawn up against his chin, and his coarse gray undershirt, which was his only garment drawn over them inclosing his entire figure. He sat there like a sort of sculptured Egyptian cat or Peruvian mummy, moving nothing but his black eyes and looking absolutely non-human. This image and my fear entered into a species of combination with each 
other. That shape am I, I felt, potentially. Nothing that I possess can defend me against that fate, if the hour for it should strike me as it struck for him ... It gradually faded, but for months I was unable to go out into the dark alone. .. . I have always thought that this experience of melancholia of mine had a religious bearing. . . . I mean that the fear was so invasive and powerful that if I had not clung to scripture-texts like "The eternal God is my refuge," etc., "Come unto me, all ye that labor and are heavy-laden," etc., "I am the resurrection and the life," etc., I think I should have grown really insane. ${ }^{8}$

This episode is followed by a journal entry in 1870 that McDermott claims is especially important for James's life and thought. James writes,

I think that yesterday was a crisis in my life. I finished the first part of Renouvier's second "Essais" and see no reason why his definition of Free Will- "the sustaining of a thought because I choose to when I might have other thoughts" - need not be the definition of an illusion. At any rate, I will assume for the present-until next year-that it is no illusion. My first act of free will shall be to believe in free will. . . I will go a step further with my will, not only act with it, but believe as well; believe in my individual reality and creative power. My belief, to be sure, can't be optimistic-but I will posit life (the real, the good) in the self-governing resistance of the ego to the world. ${ }^{9}$

These episodes are, as McDermott notes, instructive for understanding James's development as a thinker. The intellectual problem of the freedom of will is secondary to the moral question of choice, and confirming this priority is approached as a task of faith. James's interest in religion emerges, I think, in the connection of his struggle with depression and the scriptural phrases and ideas that helped him arrive at the platform of willful self-direction he discovers.

What I find most interesting about these accounts is James's awareness of his own crisis of transformation. First, he is aware that he is susceptible to a negative transformation, into a form like the asylum patient. Without a positive content or focus, James feared becoming like thatwithdrawn, unable to communicate, unable to act, unable to appear human. In the journal entry, however, James moves completely beyond the framework of despair, deliberately latching on to the prospective significance of his own free action. The possibility and potential of this act overwhelms, for the time, his intellectual doubts about the freedom of the will. In respect to the first occasion above, this prospective attitude is 
possible in light of a God who claims, "I am the resurrection and the life." James's description of religious experience as focusing on dependence obviously connects here. Moreover, his philosophical modus operandi of combining religious warrant and prospective intellectual ground has a clear antecedent in his own experience of transformation.

I think the energy that drives James to write Varieties of Religious Experience emerges from this personal ground of his own character development. Religion plays a part in James's encounter both with his despair about his "shape," and the reality of his freedom to mold that "shape."'The role religious hope sometimes played in his life, and the role it ought to play in the general hope of human transformation and strenuous living, is at stake in Varieties. For this reason, I find Varieties much less a species of observation than a prolonged persuasive essay. Or, as Ralph Barton Perry puts is, Varieties is James's justification of religion. Perry connects this justification with James's recollection of his "father's cry" that religion is real, and that "the thing is to "voice' it so that others shall hear." ${ }^{10}$ Varieties may, in fact, be James's best sermon.

Given this relation between his own transformation and his religious thought, I find it fascinating that James's philosophy of transformation does not rely on the language or tradition of a community. His careful avoidance of borrowed language means that philosophy has to speak a double word. Philosophy is pressed into service as the language and context for the transformation to the strenuous life, yet it also continues to work in its accepted role as a tool for critical evaluation. Sometimes the priority of raising the banner of strenuous character overwhelms the task of philosophical critique. But James must defend the ambiguity of the role of philosophical argument in order to secure his larger project. Defending this position, I think, propels James to claim that philosophy cannot produce any final evaluative judgment, either of a person's character or of the particular meaning of an idea. His resistance to finality spreads over both the sufficiency to interpret the many "demands" people live under and the "clash of temperaments" that describes philosophical debate. Philosophers neither can nor should seek resolution in a final, single, or ultimately determinative meaning.

James's defense of his peculiar philosophical manner and his emphasis on transformation set the stage for his dramatic encounter with religious experience and Christianity. Any philosophy that has finality as its origin or telos receives explicit repudiation. Any religious system that locates the 
content for transformation in a hard and fast way, either in historic truthclaims or explicit moral demands, assaults James's "individual reality and creative power." His resistance is honest. His transformation arises within himself and by his own will; any suggestion that it happened otherwise would compromise his ground and his character. But extending this position beyond himself philosophically means that no particular conclusion to life, to transformation, or to moral obligation can stand in the universe.

Fleshing out this philosophy of freedom and moral openness demands a kind of rebirth for James. Born into the world where finality and permanence are most often the hallmarks of the good, James enters a new world that is largely unacknowledged by the religion and philosophy of his culture. In his world, finality is equivalent to death. But his rebirth is apparent only in his confidence that he can find a way through the many pitfalls of finality and despair in the reflective life, traversing a path that can be navigated only by careful articulation and persuasion. Religious experience represents a part of human life with a high concentration of pitfalls, so James is compelled to confirm his transformation by plowing through the varieties of religious experience.

Despite his reservations about final claims and orthodox Christian beliefs, James is attracted to the character of primitive Christianity. The willingness of early Christians to act on truths that demand absolute and reckless commitment without the possibility of intellectual certainty attracts him. He wants to share in a ground that gives him hope his action is not in vain. Only in a state of action-sans-certainty can human life be fully open to creative power and all its possibilities. James's many arguments for the value of religious meaning are based on the expectation that more creative power for action is available within such a world than in a world that rejects religious meaning. Suckiel points to the following passage from Varieties that bears out this ethical point: "If radically followed, [the precept love your enemies] would involve such a breach with our instinctive springs of action as a whole ... that a critical point would be practically passed, and we should be born into another kingdom of being." "This expectation for creative action via the religious worldview is so central to James's philosophical position that it amazes me that a philosopher such as Richard Rorty can miss the import of James's religious arguments so badly. ${ }^{12}$ On the other hand, despite the positive value for creative action we find in James's account of religious 
experience, his own critique of conversion in Varieties of Religious Experience undermines the ground of personal transformation that he tries so hard to secure philosophically.

\section{CONVERSION IN VARIETIES OF RELIGIOUS EXPERIENCE}

James's charged religious moralism and his desire for an interaction with a compelling, life-transforming obligation would seem to be compatible with religious conversion. James's use of the biblical imagery in "setting before you this day" the alternatives of life and death supports this view. But in chapters 9 and 10 of Varieties of Religious Experience, James argues that conversion is not the ground for the creative transformation that he seeks. ${ }^{13}$ Rather, he argues that religious conversion, as an instantaneous event revealing a new center of the person in a dramatic and unanticipated way, is incoherent, unnecessary, and dangerous. It is incoherent because no "distinguishing mark" separates converted persons from the unconverted. It is unnecessary because natural transformation produces the same results. And it is dangerous because diabolical ideas may, in fact, be imported into such instantaneous transformations. The religious view does not, nay cannot, either depend on or benefit from a conversion event.

This argument represents a significant shift in James's account of religious experience. His warm appreciation of religious experience for its unique value in responding to "objective ends that call for energy, even though that energy brings personal loss and pain" (VRE 45) changes dramatically. Instead of arguing for the power and possible significance of an event like a conversion experience, he focuses on what is potentially wrong with it. I think something about conversion worries James, perhaps because it undermines his own account of the transformation necessary for the religiously powered moral life. He aims to set aside this eminently practical aspect of religious experience and reduce its hold on reflective minds by capitalizing on the conversion anxiety in his readers.

James's treatment of conversion moves in three ways. First, he reduces conversion to a defensive position. In the first paragraph of chapter 9 he states that, in general, conversion signifies the process whereby "a self hitherto divided, and consciously wrong, inferior and unhappy becomes unified and consciously right, superior and happy ... whether or not we believe a direct divine operation is needed to bring such a moral change about" (VRE 189). Later in the chapter he recognizes "man's liability to 
sudden and complete conversion" as one of our more "curious peculiarities," and then asks, "What, now, must we ourselves think of this question? Is instantaneous conversion a miracle in which God is present as he is present in no change of the heart less strikingly abrupt?" (VRE 230). The posture here is more instructive than the words. From the outset James involves his readers in evaluating conversion from some ground beyond the description of its occurrence or the ground it claims for itself. James introduces a division between conversion and the divine, and his examination turns on exploiting this separation.

Second, James critically examines several experiential characteristics of conversion based on the presumption that these effects are all that can be said about conversion. He draws his data from personal experience and the accounts of such representative thinkers as St. Paul, Martin Luther, and Jonathan Edwards. Edwards appears as the authority most closely identified with the suspicious doctrine of conversion. James's attachment to Edwards is significant because they have very different conceptions of conversion. There is something of a battle of wills or a clash of temperaments going on in these chapters, and it is to James's credit that he selects a strong opponent. Recall that Edwards says no genuine conversion is possible without God's immediate presence, and that if God were present to a person it would affect a complete reorientation of the person's affections, of all their ideas and all their desires. The rhetorical value of a critical appropriation of Edwards into James's psychological account of religious experience would be dramatic. In the heat of battle, however, I think James either seriously mistakes or intentionally misrepresents Edwards's understanding of conversion. He does so in part, I think, in order to avoid confronting some of the deeper issues that are at stake here. We will take up this examination in a moment.

The third movement within James's argument builds from the opposition that grows between him and Edwards. James argues that the good desired in conversion can be explained better as a natural than a supernatural transformation, and that the expectation of a sudden or momentary change of character undermines the prospects for creative transformation. James plies the positive side of this argument as well, suggesting that redeeming the "fruits of evangelicism" (VRE 239) requires a different kind of distinction between people than the bifurcation of "converted" and "unconverted." Such an abrupt distinction is too pedestrian to work as a satisfactory account of religious transformation that accesses the 
higher and lower limits of a person (VRE 230). Such criticism of sudden or momentary conversion that separates souls into two distinct categories carries for many later American religious thinkers, including the superbly articulate account in H. Richard Niebuhr's Christ and Culture. ${ }^{14}$

Part of my aim here is to show the seriousness with which James addresses conversion. He alone among American philosophers gives the topic careful consideration. But I also want to demonstrate the effectiveness of the argument James makes against conversion. James is in such complete control of his text that his rejection of conversion is not an unintended by-product of his larger religious view or a rhetorical overstatement. Conversion pushes James's philosophy beyond its limit. Uncovering the basis for his resistance to conversion will enable us to see a different side to his account of obligation and personal transformation.

\section{Conversion on the DeFensive}

James's suspicions about conversion are warranted. It would be absurd to accept uncritically an event where "religious aims form the habitual center of [a person's] energy" (VRE 196). Adding the conception of divine influence to such an event raises further questions that must be answered. James's focus on conversion is good; his suspicions are justified. But the facts are that the curious notion of conversion is a central tenet of Christian doctrine. It is not a peculiarly American or evangelical invention. Christianity is built on the foundation that interaction with divine power remarkably changes a person into a "new creature."15 Conversion is not a tangent of theology but the very heart of the Christian tradition, as Karen Armstrong points out in her work on Islam. ${ }^{16}$ Conversion is Christian territory. James knows this. My unhappiness with James is not that he examines conversion critically, but that he does not examine it critically enough. His program limits inquiry into conversion, and thus limits inquiry into the obligation that stands behind religious experience.

James creates the rhetorical space for his argument against conversion by asking his auditors at one point to wait for his assessment of the divine aspect of conversion until he has made some "psychological remarks" (VRE 230). Holding the divine aspect of conversion in abeyance allows James to lay out another frame for the change of disposition toward 
religious life. This frame of expansion includes "the Subject's range of life," and "a new sphere of power" (VRE 48).

This psychological inquiry hides a critical strategy, though; it is part of a tactic of holding tough questions in abeyance that begins early in the book. James is not simply offering an objective description of religious experience and conversion, that is, using personal narratives on the one hand and psychological terms on the other. He is bringing religion and conversion to a critical philosophical test. "If the fruits for life of the state of conversion are good," he says bluntly, "we ought to idealize and venerate it, even though it be a piece of natural psychology; if not, we ought to make short work with it, no matter what supernatural being may have infused it" (VRE 237, my emphasis). James introduces the prospect that conversion may not yield good results for human life, effectively shifting the ground under conversion. Its position seems precarious. By suggesting that we "make short work of it," I take him to mean that if conversion is not in some way demonstrably good for us, we ought reject it and eliminate it from our conception of good religious experience. The burden of proof is therefore placed on the side of those who claim that conversion is good; they must show that it is good for life, and also that it does not warrant suspicion. James has sealed off the argument that conversion is good because of its divine origin, having narrowed the description of "religion" and "good" to effects obviously apparent in the active life of the subject. Thus, he demands from conversion an answer he knows it cannot give.

Examining religious experience in this way represents a remarkable shift away from James's willingness to embrace the infinite perspective of moral obligation that comes with an awareness that "God is there" in "The Moral Philosopher." It reveals an inconsistency in James's thinking that needs sorting out. Why does James find himself in such opposition here? The reason for this opposition is more evident when we consider his interaction with Jonathan Edwards.

\section{EDWARDS'S AFFECTIONS IN VARIETIES OF RELIGIOUS EXPERIENCE}

Jonathan Edwards's Religious Affections and William James's Varieties of Religious Experience are the two most significant books in American religious thought. Edwards and James both seek the reality behind religious experience, but they reach conflicting conclusions. Edwards 
discovers the rules or patterns in experience that enable individuals to judge whether their affections have been graciously (divinely) changed, since if God desires such a change in us God will also enable us to know it. Human transformation is completed by divine influence and known by discovering this divine influence in our affections, our "lively actings of the will or inclination" (Religious Affections [RA 98]). James arrives at a quite different conclusion. What is most good for human life is good whether there is a divine influence behind it or not. James argues that if religion is good for life, then all of its aspects should be accounted good, including claims of divine influence. Conversion is a problem, however, because it testifies to a direct divine influence on the individual's life, and this dependence on the divine moves the achievement of the religious life out of the range of human power or philosophical understanding. This dependence on divine power, taken as a negative limit, is the aspect of conversion that James finds most unfruitful for life.

Although James and Edwards are clearly at odds, James refers to the Religious Affections several times, primarily as he concludes his own remarks on conversion. I think James plays on Edwards's authority by casting his own psychological formulation over Edwards, subtly leading the reader toward the claim that there are more important tasks than establishing the divine ground of transformation. If an explicit philosophical incompatibility between James's description of religious experience and orthodox Christian belief arises, it will appear in regard to conversion. ${ }^{17}$ But James wants to avoid a showdown between himself and orthodox theologians like Edwards, if this is possible. To avoid this fight James must persuade his readers that they can be Christian and religious-even more religious-without conversion.

James uses Edwards in the introductory lecture of Varieties to support his basic premise that effects in life are the only suitable grounds for assessing the value of religious character. He attributes this passage to the Religious Affections, though he does not give the reference for any of his uses of this book. In forming a judgment of ourselves, Edwards says (according to James), we should use the same evidence that God uses: "The degree in which our experience is productive of practice shows the degree in which our experience is spiritual and divine" (VRE 20). James sets this up by attributing to Edwards the idea that "the roots of a man's virtue are inaccessible to us. No appearances whatever are infallible proofs of grace" (VRE 20). Edwards would, in fact, agree with this, 
because any final judgment is God's business alone. But that is not the force of the point James is trying to make. James implies that searching after "the roots of religious virtue" is a problem because these roots cannot be known, and they actually do not make a difference when our focus is on the quality of our practice; at best, they are a distraction. James lobs this problem in Edwards's direction. For Edwards, though, determining the roots of one's affections is both challenging and necessary, since without this inquiry we will not know whether the truth of our condition is based on God or self-deception.

James again cites Edwards in the discussion of the form of conversion as a matter of social suggestion. In a footnote (VRE 200), he records a passage where Edwards notes that the pattern of conversion is clearly influenced by suggestions from the social practice of religion. James takes this as confirmation that the form of conversion has more to do with following cultural expectations than finding divine roots. But Edwards's point in the text is very different. In fact, this passage is from Part II of the Affections, where Edwards is giving an account of what are not signs of truly gracious affections. Following steps or conventions gives us no ground for considering our hearts to be genuinely affected by God, since even Satan can reproduce steps in our experience. What Satan cannot do is reproduce the content of the gospel in such a way as to change souls. This is the unequivocal sign of God's grace. Again, then, James draws on Edwards's authority, but their points do not lie together.

In both of these instances, it would take a reader familiar with the Religious Affections to see the depth of philosophical separation between Edwards and James. This separation becomes much more apparent in the culminating instances of James's use of the Religious Affections and his use of David Brainerd. The Life of David Brainerd, a narrative of the life and service of the missionary to the Delaware Indians, has a history of its own. David Brainerd was a friend and admirer of Edwards. After his dismissal from Yale, Brainerd stayed with Edwards before he began his mission work. Brainerd returned to Edwards's home after his missionary tour, deathly ill, recounting his journey and delivering over his journal. Edwards's daughter Jerusha nursed Brainerd as he died, then followed him in death a few months later. Their graves are side by side in recognition of their deep spiritual communion.

Edwards edited Brainerd's journal, added an introduction, and gave it the title The Life of David Brainerd. The popularity and influence of this 
book exceeded all of Edwards's other writings both domestically and abroad. The Life of David Brainerd is regularly cited as the inspiration for the modern missionary movement, with Brainerd's example becoming the acme of personal piety and self-sacrifice for the cause of Christ. Joseph Conforti quotes John Wesley, who edited and distributed his own version of this book, as saying: "Let every preacher read carefully over The Life of David Brainerd. . . Let us be followers of him, as he was of Christ, in absolute self-devotion, in total deadness to the world, and in fervent love to God and man." 18 Brainerd was not only Edwards's ideal saint, but he was also canonized as the model of vital piety and Christian service for most of the nineteenth century.

James quotes from David Brainerd's narrative at the end of chapter 9 before moving into his critical analysis of conversion. In the passage quoted, Brainerd describes his resistance to the persuasion of Christ, his inability to affect the change he desired by his own will, and his ultimate yielding to God: "I was attempting to pray; but found no heart to engage in that or any other duty. ... I thought God had quite left me. ... Then as I was walking in a thick grove, unspeakable glory seemed to open to the apprehension of my soul. I do not mean any external brightness, nor any imagination of a body of light, but it was a new inward apprehension or view that I had of God" (VRE 213). James uses Brainerd's narrative to describe the condition of emotional exhaustion that often attends conversion. In such cases the "exhaustion of the lower and the entrance of the higher emotion" is simultaneous, James says (VRE 214), and this reveals the subconscious ripening of the one affection and the exhaustion of the other. The pneumatic language of this exchange of emotional states is the subtext for James's chapter on conversion, and for this reason James does not reflect on Brainerd's claim of a "new inward apprehension of God"; he only notes that Brainerd moved from exhaustion to a glorified peace. This emphasis on Brainerd's emotional state, while discounting the content connected with the emotional state, parallels James's direct response to Edwards.

James's emphasis on Brainerd and the emotional state of exhaustion are certainly strategic in this argument about conversion. The psychological description of Brainerd's conversion as the result of exhaustion and being overwhelmed in weakness by a "higher activity" is a direct challenge to Edwards. James's suggestion is that Brainerd's state of exhaustion and loss of control are determinative for the likes of Edwards and other advocates 
of conversion. Conversion and critical philosophical reflection must therefore be incompatible. Brainerd, as Edwards's most noted disciple and exemplar, makes the path of conversion appear hyperbolic. The close association between Brainerd and Edwards, which would have been very clear to James's auditors in Scotland and at home, sets up James's explicit conflict with Edwards.

James closely aligns Edwards with this depiction of conversion as dubious and dangerous. Reliance on social suggestion, the common feature of psychological exhaustion, the strong desire for safety and the instantaneous effect of this change-all these ideas circulate around Edwards. James praises the religious power of the conversion experience, and he calls Brainerd an original saint, since there is no doubting his presence and power in the story of American Christianity. James then glosses the Puritan thinker Henry Alleine and Edwards together, writing, "More-over the sense of renovation, safety, cleanness, rightness, can be so marvelous and jubilant as well to warrant one's belief in a radically new substantial nature" (VRE 228). Notice that into this sentence James slips the warrant that a "new substantial nature" is a conclusion drawn from the quality of the marvelous sense of safety and jubilation, not from the content of intellectual, scriptural, or philosophical descriptions. He quotes from Edwards's Religious Affections to support this connection between a "new substantial nature" and certain gathered effects. James quotes at length from the Religious Affections:

Those gracious influences which are the effects of the Spirit of God are altogether supernatural-are quite different from anything that unregenerate men experience. They are what no improvement, or composition of natural qualifications or principles will ever produce; because they not only differ from what is natural, and from everything that natural men experience in degree and circumstances, but also in kind and are of a nature far more excellent. From hence it follows, that in gracious affections there are also new perceptions and sensations entirely different in their nature and kind from anything experienced by the same saints before they were sanctified. (VRE 228-229)

The new perceptions mentioned here seem to correspond to the ideas that appear on the ragged edge of consciousness, as James describes it. These appearing ideas become the ground for claiming divine significance due to the overwhelming pressure the subject feels in relation to them. In this way, the "supernatural" is an addition to these perceptions. James 
continues quoting from the Affections concerning the bifurcation of a person's experience into one of two states: life without grace, and life with it.

As those who are saved are successively in two extremely different states of justification and blessedness-and as God, in the salvation of men, deals with them as rational and intelligent creatures, it appears agreeable to this wisdom that those who are saved should be made sensible of their Being, in those two different states. (VRE 229)

Edwards's statements seem to cohere very nicely with James's theory. Based on the experience of a dramatic shift in perceptions and sensations a person is able to claim the presence of divine influence. And this divine influence is extended to mean a complete sundering of the old man from the new-the sinful man from the grace-filled man. These additions to the experience of transformation are in view when James says,

What, now, must we ourselves think of this question? Is an instantaneous conversion a miracle in which God is present as he is present in no change of heart less strikingly abrupt? Are there two classes of human beings, even among the apparently regenerate, of which the one class really partakes of Christ's nature while the other merely seems to do so? Or, on the contrary, may the whole phenomenon of regeneration, even in these startling instantaneous examples, possibly be a strictly natural process, divine in fruits, of course, but in the one case more and in another less so, and neither more nor less divine in its mere causation and mechanism than any other process, high or low of man's interior life? (VRE 230)

James retraces the lines of Edwards's inference. From the claim of divine nature, we can regress to the experience of dramatic change without losing any descriptive power. Edwards's suggestion that two discrete states of the person would clearly appear is treated more condescendingly. Are there really two classes, James asks, two utterly separate parts of humankind with no continuity between their moral existences? What fruits could support such a claim? Are the differences in the active lives of such people so stark that a difference in divine status can be claimed? If the goal of religious life is good fruit, the good fruit is all that matters, not an obscure and problematic division between converted and nonconverted. No such distinction is possible, James says, and the issues of divine ground, instantaneous change, and a unique and comprehensive alteration of character are unnecessary additions to the natural process of change and growth. 
This claim rests on James's conviction that responding religiously to moral obligation does not include such a once-and-for-all change, or the knowledge of such a once-for-all change. James puts it this way:

Were it true that a suddenly converted man as such is, as Edwards says, of an entirely different kind form a natural man, partaking as he does directly of Christ's substance, there surely ought to be some exquisite class-mark, some distinctive radiance attaching even to the lowest specimen of this genus, to which no one of us could remain insensible, and which so far as it went, would prove him more excellent than ever the most highly gifted among mere natural men. But notoriously there is no such radiance. Converted men as a class are indistinguishable from natural men; some natural men even excel some converted men in their fruits; and no one ignorant of doctrinal theology could guess by mere everyday inspection of the "accidents" of the two groups of persons before him, that their substance differed as much as divine differs from human substance. (VRE 238)

One wonders what kind of class mark James would accept even if Edwards could describe it. My guess is that there would never be a "distinctive radiance" of which no one could be insensible, so this criticism is disingenuous. Everyone will fail to meet a standard that no one, by definition, can meet, but very little is gained by pointing this out. I think James's remark here hides a deeper purpose. At every critical juncture James reinforces the centrality of fruits in forming our religious self-conception, but he has cleverly transformed the expectation of these fruits into philosophical terms of stability and freedom instead of the "fruits in keeping with repentance" that grounds this biblical phrase. These are the fruits by which Jesus claims we can discriminate false teachers from true, not those that attest to our freedom or our action.

James's remark about a radiance that cannot be found is a further critique of Edwards's claim that believers are asymmetrically dependent on divine content in their understanding of conversion. Since we can identify fruits, and since we can manifest them or not by our willingness to make them our "center of energy," James argues that we are not dependent on a tradition, scripture, or divinely revealed content in order to have the good of religious experience. This conflicts somewhat with James's earlier depiction of religion as awareness of our dependence. What James is doing here-especially in light of what he has to say on conversion-is redefining religious dependence. "For when all is said and done," James says, "we 
are in the end absolutely dependent on the universe; and into sacrifices and surrenders of some sort, deliberately looked at and accepted, we are drawn and pressed as into our only permanent positions of repose" (VRE 51). This dependence is not without deliberation, even in this high prose, and therefore obligation in moral and religious life falls more on the side of "choose this day" than "See, I set before you life and death."

I think James has to "make short work" of conversion in this way because the very notion of conversion exposes a problem in his understanding of obligation. He recognizes the abrupt character of moral and religious ideas and their emotional influence. Yet, he also wants to make room for Emersonian religion, the religion of the healthy-minded. If Brainerd is Edwards's ideal saint, Emerson is James's, despite the fact that James is clearly a sick soul himself. After all, he did require a year to recover his emotional equilibrium before he could write Varieties of Religious Experience, Josiah Royce graciously taking his place in Edinburgh during his absence. James wants to secure the healthyminded passage through life even if he is not constitutionally able to live it. He longs for that stability that would anchor each moment of volition; "whereas the merely moralistic spurning takes an effort of volition the Christian spurning is the result of an excitement of a higher kind of emotion, in the presence of which no exertion of volition is required" (VRE 46). James seems to move between affirming and rejecting this kind of life. The stability of a converted character attracts him; the finality of a converted character repels him. He is clear that "[religion] ought to mean nothing short of this new reach of freedom for us. With the struggle over, the keynote of the universe sounding in our ears, and everlasting possession spread before our eyes" (VRE 48). "So with the conversion experience," he concludes, "that it should for even a short time show a human being what the high-water mark of his spiritual capacity is, this is what constitutes its importance which backsliding cannot diminish, although persistence might increase it" (VRE 257). James wants the place of the converted, but without the content of a tradition to limit or define him or his choice.

Oddly, Edwards agrees with James. It is true that there can be no single emotional center for the many religious or converted souls. Such a center would set up opposition between the one and the many, and also between the person and himself or herself. Nor does Edwards seek a limiting content in conversion, but rather an access to a "new world of 
knowledge." This is why, in opposition to James, Edwards rejects "new perceptions and sensations" as the proper ground of conversion. Rather, he claims that a different discovery is made. Let me return to the passage from the Affections James quoted earlier. Where James cites Edwards pointing to "new perceptions and sensations," Edwards's unabridged text reads, "through the saving influences of the Spirit of God, there is a new inward perception or sensation of their minds, entirely different in its nature and kind from any thing that ever their minds were the subjects of before they were sanctified." Edwards's focus is the content that appears in the mind, the person's perception of himself or herself. To continue, Edwards says that what appears in the mind is "what some metaphysicians call a new simple idea" (RA 205). These words do not appear in the text James apparently used for Varieties, which is an emended and abridged version produced as a volume of the Evangelical Family Library. ${ }^{19}$ The "new center" of the person cannot be a combination of any naturally occurring ideas, but can only distinguish the mind as being aware of a completely new content-which is discovered in the mind, in its products, in the person's affections.

Edwards prefers to call this a discovery of a new foundation in the soul. This foundation is not a philosophical accomplishment or a product of the mind, but the creation in the heart and mind of the individual of a new kind of reflective order. The new ideas we have are not miraculous or divine, but the new idea we have of ourselves is. James found the right passage but did not have the right text. Still, from a more thorough reading of the text he did have, James could have found this statement:

What a spiritual conviction is, we may ascertain from what has been said already of spiritual knowledge. Conviction arises from the illumination of the understanding. ... Hence it follows that a spiritual conviction of the truth of the gospel is such a conviction as arises from a spiritual view or conception of the Gospel. And this is also evident from the Scriptures, which often represent a saving belief of the reality and divinity of the things exhibited in the Gospel, as springing from the enlightening of the mind by the Holy Spirit, so as to give us a right conception of those things. (EFL 169)

In this passage and many others, Edwards connects the illumination of the mind with the discovery of the truth of the Gospel concerning Jesus Christ. As I have said in other places, the dual character of the self and 
the content of the Gospel are closely related for Edwards. The discovery of the "simple idea" in the Gospel parallels the discovery of the new foundation in the soul. But this kind of asymmetrical dependence on the Gospel for religious discovery is antithetical to James's account of conversion and his account of religious experience.

James won the battle for conversion, at least in the court of common appeal. But I think he lost more in this battle than he gained. His understanding of obligation undergoes changes in several ways in order to negotiate the waters of conversion, and these changes reveal some of the philosophical weaknesses of his account of moral living and religious experience. These weaknesses, though, point us in the direction of some further transformations necessary for understanding obligation.

\section{Transforming OBLIGATION}

James reminds me of the sort of person who likes to preach but cannot stand to listen to a sermon by someone else. He brings his readers to the point of realizing their choice about which world they will occupy. All of his essays are persuasive; he wants to move the reader to his position. This is what makes him an excellent philosopher-his arguments are never useless icons, they are working thoughts. They aim to have an effect.

The effect James has on me when I read this text is that I am aware of his transference of religious expectation from the world to the individual. Whatever is religious in the universe is for the well-being of individuals, for James himself as a matter of fact. When I read Varieties, I am most struck by the idea of "what the universe does, or should do, for me." I think this is the reason James's treatment of conversion rubs me the wrong way. It is all about the subject. If our deepest religious experiences are idiosyncratic, if they do not put us into commerce with a community, the critics of religion are right to condemn them, as Patrick Dooley notes. ${ }^{20}$ If the height of religious experience only confirms my success in prescinding the meaning of the universe into the transformation of my emotion, then what have I gained? What connection is there between my success and the moral state of the universe? Whether conversion is moral or metaphysical, stretching out from my own personal experience to the reality of human experience beyond me is essential. James faced this problem in the "Moral Philosopher" when he claimed that every moral impulse requires a kind of universal applicability. He was once prepared to 
bring this universal sense of obligation to the fore. But the universality of obligation breaks down under pressure from conversion. There must be transformation, James suggests, but the problem of conversion makes him adjust the concept so that there cannot be one transformation for all people, nor even one impulse toward transformation for all people. Obligation is many, not one, he now claims. But this fragments the very aspect of moral inquiry and universality James expects to build on.

Something vital is lost here. What I miss most in Varieties is challengeany sort of intellectual, moral, or philosophical challenge. The religious landscape unfolds before James, and it seems there is no place he cannot travel and remain stably secure in his thinking. But this means religious inquiry is not like an intellectual inquiry on the edge of discovery-there is no absence or conflict James must struggle against. Religious thinking is no longer a source from which we can expect new ideas and new developments of thought and philosophy. There is no resistance in religion; there is only the resistance of religion. There are problems to overcome in religious expectations, but not something that might overcome us and the resistance we embody. For James, religion is ultimately about a willful expansion into "an objectively existing higher level of consciousness, in which we all participate," as Ellen Suckiel puts it. ${ }^{21}$ Religion cannot get us anywhere intellectually that we cannot get in some other way. That is what I miss most in James's account of religious experience.

And yet, this attitude toward religion is apparently neither here nor there to James. He must not miss what I miss, or he would have approached things differently. But I do see a problem in James's theory about obligation as a result of this condition of idiosyncratic religion. It moves him back from his expectation of a metaphysical overcoming through the moral life to the casuistic mode he desires to leave. The casuistic mode is the state in which every act of will involves keeping our highest goods topmost, as he says. This continual mindfulness is opposed to the overcoming to which James calls attention in the beginning of Varieties. Religion is the state in which the power of higher goods becomes the "center of energy," and from this state no backsliding will ever remove us. But James resists this once-and-for-all change, or the change that opens the person to another world of metaphysical substantiality. He resists these conversionistic images and remains with the casuistic.

This return to the casuistic is a philosophical retreat. That James does so return is evident in his fear of the diabolical. Describing instantaneous 
conversion, he says, "But in any case the value of these forces would have to be determined by their effects, and the mere fact of their transcendency would of itself establish no presumption that they were more divine than diabolical" (VRE 243). Evaluating the forces behind a sudden transformation requires examining their "fruits," their results in our action. To speak broadly, therefore, we cannot know whether the forceful emotional impulse in conversion is a good unless we have it stretched out into practices, and these practices can be evaluated in terms of good or ill. Only by virtue of this casuistic evaluation can we determine the divine or demonic character of the force working on us.

James puts this worry forward as another reason to turn away from the expectation of sudden conversion. But the problem is a bit deeper than James realizes. If we must evaluate the force in instantaneous conversion, must we not also evaluate the force at work in what James calls "natural transformation"? Using the term natural seems to qualify this force as less troublesome - it is natural, not manufactured. But its form has little to do with its quality of effect. I am sure that a natural transformation could produce the same demonic outcome as a sudden transformation. The form of the transformation gives James no way to distinguish between forces natural, sudden or otherwise. They all must be measured by the standard of "fruitful for life." And this means that the moral soul can never attain a place of stability based on the significance, power, or form of religious transformation. To put it a slightly different way, there is never a platform individuals can attain, from which they can suppose that all they do or endure has meaning. Meaning-moral meaning-is only retail, never wholesale. This is significant because this is not where James wants to end up, and if this description is correct, his philosophical account of the obligation that attends the claim "God is there" in the "Moral Philosopher" goes begging in Varieties.

The moral life, obligation itself, arises for James as the result of an encounter with despair and freedom. His worry about the shape that he might become - that inhuman shape of the asylum patient — casts James into despair. If that should come to him, he knows not whether he could overcome it. His despair is not overcome by the conviction that he is able to attain freedom by the force of will. His freedom is like the weight resting on one end of a cantilever bridge. This weight must increase as the bridge extends, or at some point the progression will tumble into the abyss. James avoids tumbling into despair so long as he 
is assured of his freedom, and his freedom is dependent on achieving further exercises of his freedom. Despair is the limit to his freedom; it is what awaits his first faltering step. And freedom is the limit of his despair-it keeps despair at bay but cannot overcome it. It does not surprise me that worry over a diabolical force sneaks into James's account of conversion. Like the evil deceiver in Descartes' meditations, it reveals more than it intends, and once invoked it cannot be dismissed. James needs obligation to overcome both the potential abyss of despair and the infinite stretching out that freedom requires. Obligation, that reality of a claim upon us that puts our action into relation with the universe as well into relation with all of our past and future actions, draws James forward in the hope that despair may have an answer in a striking conviction of certainty, or at least in a method of outliving despair. Obligation answers freedom by proposing a content to guide the exercise of faculties and desires. It proposes a limit that does not restrain freedom, but makes freedom meaningful.

The transformation of obligation is incomplete in William James's writing. Obligation remains the feature of his moral and philosophical thought that eludes him. The problem of conversion reveals where James most clearly sees his desire leading, but he hesitates to yield his freedom to the discovery required in conversion, where the content stands beyond him and critiques his efforts. For James, conversion is a repetition of the state of the asylum patient-sitting and waiting, a life of exhaustion, unable to have control over what holds him.

William James marks a significant step toward the understanding of religious and moral obligation in American religious thought. James illuminates the conversion anxiety that lurks within our collective soul, and which still evinces the lingering influence of Edwards. James also illuminates the philosophical problematic of adapting language to address, and perhaps overcome, this anxiety. But I do not think that James overcame this anxiety, and to the extent that he did not, his philosophical transformation of obligation remains incomplete.

\section{NOTES}

1. Ellen Kappy Suckiel, William James's Philosophy of Religion (University of Notre Dame Press, 1996), 3.

2. Stanley Hauerwas, With the Grain of the Universe (Brazos Press, 2001), 85. 
3. Suckiel, James's Philosophy of Religion, $20 \mathrm{ff}$.

4. Charlene Haddock Siegfried, William James's Radical Reconstruction of Philosophy (SUNY Press, 1990), 47.

5. See Robert J. O'Connell, S.J., William James on the Courage to Believe (Fordham University Press, 1984), 99-102. O'Connell emphasizes the martial and heroic images of James's moral language, which carry the deontological freight of "doing the universe the deepest service we can."

6. William James, Pragmatism: A New Name for Some Old Ways of Thinking (Longmans, Green and Co., 1914), 289.

7. Ibid., 286-287.

8. John Stuhr, ed., Classical American Philosophy (Oxford University Press, 1987), 95.

9. Ibid., 94-96.

10. Ralph Barton Perry, The Thought and Character of William James (Vanderbilt University Press, 1996), 41.

11. Suckiel, James's Philosophy of Religion, 110.

12. Richard Rorty, "Religious Faith, Intellectual Responsibility, and Romance," in Pragmatism, Neo-Pragmatism, and Religion, ed. Charles Hardwick and Donald Crosby (Peter Lang, 1997). This essay receives an extended response in chapter 8 .

13. Patrick Dooley, Pragmatism as Humanism (Nelson Hall, 1974), 99.

14. H. Richard Niebuhr, Christ and Culture (Harper \& Row, 1951), 251. Niebuhr formulates his "ultimate question in this existential situation" as one that divides between "reasoning faithlessness" and "reasoning faith."

15. A. D. Nock, Conversion (Oxford University Press, 1933), 14. Nock traces the development of conversion from Oriental and Hellenistic religions prior to the advent of Christianity. In this way, Nock shows that Christian conversion is deeply rooted in human religious identity and practice.

16. Karen Armstrong, Islam: A Short History (Modern Library, 2002), 30.

17. This is why I disagree with the way Hauerwas responds to James. Getting after James on the question of God is a losing battle, because it just turns out that God, though real, is impossible to make into an explicit foundation for religious life. If James draws us into this rocky ground he may not beat us, but he will keep us pinned down forever, whereas the reality of transformation can be like the same ground only inverted-so that any argument for transformation, and James has plenty, are difficult if not impossible to limit to purely natural conclusions.

18. Joseph A. Conforti, Jonathan Edwards, Religious Tradition, and American Culture (University of North Carolina Press, 1995), 69.

19. Edwards on the Affections and Alleine (American Tract Society, n.d.). Subsequent references in the text are noted EFL and page number. 
20. Dooley, Pragmatism as Humanism, 102. Dooley describes conversion in VRE in its positive light, and handles the natural-supernatural question of origin as one based on the fruits of the converted person. "However, if surrender to God issues in a commitment to fellow men, it promotes a better society. In this society, charity and love of fellow man encourage human excellence-respect for the sacredness of all persons and tolerance of individual differences."

21. Suckiel, James's Philosophy of Religion, 121. 